\title{
Hospitals as innovators in the health-care system: A literature review and research agenda
}

\author{
Taran Thune ${ }^{a, *}$, Andrea Mina ${ }^{b}$ \\ a TIK Centre for Technology, Innovation and Culture, University of Oslo, Norway \\ ${ }^{\mathrm{b}}$ Cambridge Judge Business School, University of Cambridge, United Kingdom
}

\section{A R T I C L E I N F O}

\section{Article history:}

Received 6 January 2016

Received in revised form 14 March 2016

Accepted 14 March 2016

Available online 7 April 2016

\section{Keywords:}

Health-care technology

Health innovation system

Hospitals

Medical innovation

User innovator

\begin{abstract}
A B S T R A C T
This paper aims to improve the understanding of the role of hospitals in the generation of innovations. It presents a systematic and critical review of the interdisciplinary literature that addresses the links between the activities of hospitals and medical innovation. It identifies three major research streams: studies of the contribution of medical research and clinical staff to innovation, analyses of novel practices developed and diffused in hospitals, and evolutionary studies of technical change in the context of human health care. This is a highly heterogeneous body of literature, in which comprehensive theoretical frameworks are rare, and empirical studies have tended to focus on a narrow range of hospitals' innovation activities. The paper introduces and discusses a framework integrating different perspectives that can be used to analyze the functions performed by hospitals at the intersection with different partners in the health innovation system and at different stages of innovation trajectories. On the basis of current gaps in the literature, a research agenda is discussed for a relational and co-evolutionary approach to the study of hospitals as innovators.
\end{abstract}

(C) 2016 Elsevier B.V. All rights reserved.

\section{Introduction}

Studies of innovation related to human health have emerged in great abundance, on topics ranging from advanced biotechnology to improvements in health services. Many of these studies argue that hospitals are central actors in this innovation, yet these organizations are rarely addressed directly and explicitly in innovation studies. Instead, they are treated as contexts, partners, indirect selection mechanisms, and users in investigations of industrial development and the commercialization of science. In this paper, we focus on the role of hospitals in the generation of medical innovations through a systematic review of the relevant social science literature.

Hospitals, in particular, university or research hospitals, are part of health innovation systems, which can be theorized as distributed systems because of their extensive division of labor and complex collaborative approach to the application of useful knowledge (Coombs et al., 2003; Von Hippel, 1988). Hospitals perform multiple functions in health innovation systems. They are the major providers of health-care services. They are adopters and users of

\footnotetext{
* Corresponding author.

E-mail addresses: t.m.thune@tik.uio.no (T. Thune), a.mina@jbs.cam.ac.uk (A. Mina).
}

new technologies (thus the demand side of externally generated innovation). They are potential developers of processes and organizational innovations. Moreover, hospitals can be an integral part of the education system in which new practitioners are trained, so they can be loci of clinical experimentation and large R\&Dperforming institutions in their own right. Overall, they are key sites for the adoption, reproduction, and generation of medical knowledge.

The role of individual doctors as innovators has been covered extensively in the history of medical technologies but has to be understood within a complex institutional environment and in relation to long-term epistemic and cultural change (Blume, 1992; Pickstone, 2011). The role of hospitals in the consumption and implementation of innovations-both technical and clinical-has also been covered extensively in the health management, health economics, and health policy fields. However, despite notable exceptions (e.g., Djellal and Gallouj, 2005, 2007; Salge, 2012; Salge and Vera, 2009), the organizational capacity of hospitals to generate medical innovations has been underemphasized. In this paper, we are interested in assessing the role of hospitals as generators of medical innovation, broadly defined as "new drugs, devices and clinical practices introduced over time into the provision of health care" (Consoli and Mina, 2009). The rise of more open models of innovation (Chesbrough, 2003, 2006; Dahlander and Gann, 2010) makes it even more important to focus on the specific contribu- 
tion that hospitals make or have the potential to make in upstream innovation activities as leading organizations or as partners to other organizations in the medical industrial complex. For this reason, we are especially interested in the literature that covers universities, research hospitals, and academic medical centers, and their arguably growing importance in modern health innovation systems.

Health-care systems comprise heterogeneous actors who perform distinct but related tasks (Djellal and Gallouj, 2005, 2007). Although there is a division of labor among the individual participants, many of the tasks performed by each agent cannot be completed without the contributions of other agents. Thus actor groups have multiple and mutual dependencies, which create the systemic quality of health innovation (Windrum and GarcíaGoñi, 2008). Hospitals, particularly research or academic hospitals, become central nodes in health-care networks because they perform multiple roles at key intersections of the system (Anderson et al., 1994; Ramlogan et al., 2007). First, these organizations function as brokers among different domains and sources of knowledge, such as scientific, clinical, technical, and commercial knowledge. Second, they are bridges among different modes of learning, including learning through medical practice, through basic and applied research, through technical experimentation, and learning by adapting new technologies to local contexts (Morlacchi and Nelson, 2011; Rosenberg, 2009). Third, hospitals connect healthcare systems across stages in the innovation process as they can be involved in idea generation, testing/verification, implementation, and diffusion.

Hospitals contribute to new idea generation through experiential learning in clinical practice and research (both basic and clinical) by identifying problems and potential solutions. They often do so in collaboration with universities and firms under a variety of institutional arrangements (Rosenberg, 2009; Schlich, 2002). The outcomes of these activities are research outputs, insights for new inventions, and candidates for new products and processes (Chatterji et al., 2008). Some of these ideas may be spun out to form the basis for new companies or are licensed to existing firms (French and Miller, 2012).

Hospitals can initiate some product development activities internally, particularly development of new procedures, new services and organizational arrangements, and new tools and methods. In the product development phase, however, hospitals mostly interact with established firms to transfer knowledge about the clinical context in which the new product candidates can be used. They are then involved in testing and documenting the effectiveness, safety, and efficiency of new product candidates, thus influencing technology selection (Windrum and García-Goñi, 2008). Activities linked to learning and adaptation in the user context is a fundamental role for hospitals, along with development of a range of service innovations to support the implementation of new technology or new treatments. In addition, hospitals can shape opportunities for technological learning because experimental practice can lead to new idea generation, both as incremental improvements upon existing techniques or services, and as ideas for new products (Djellal and Gallouj, 2005; Metcalfe et al., 2005).

Fig. 1 describes the multiple roles that hospitals can play in the generation of novelty within health care and medicine, which sets the parameters for the present study. Without implying strict linearity in these stages or dimensions, we propose that at any point in time a range of parallel and stepwise innovation activities occur in relation to the organizational context of a hospital.

The twin objective of the paper is to provide an overview of the state of the art on this interdisciplinary problem and to outline a conceptual framework that can be applied to the study of hospitals from an innovation system perspective. By highlighting the multiple roles hospitals play in distributed health innovation systems, we argue that the contribution of these institutions must be understood in relational and co-evolutionary terms: hospitals are sources of novel ideas as well as conduits for innovation generated elsewhere is the system. We argue that a more comprehensive perspective on the role of hospitals is important to better inform policy by stressing the system-level impacts hospitals have on the innovative performance of health-care service and manufacturing activities.

We use a systematic review methodology and sample widely in the heterogeneous and multidisciplinary research literature on this topic. In the next section, we present our methods and data. Three thematic strands of contributions emerge that differ in their perspectives and levels of analysis, which are articulated in more detail in Section 3. In Section 4, we synthesize and discuss the key findings. Having identified contributions and knowledge gaps, Section 5 concludes by highlighting emerging issues for further research.

\section{Review method}

The paper is based on a systematic review approach (Littell et al., 2008), which aims to make the literature selection and review process transparent and replicable. We started from the factual premise that research on hospitals and innovation spans many disciplines, empirical approaches, and publication channels. A highly heterogeneous body of knowledge presents the challenge of capturing the breadth of relevant contributions and synthesizing insights and main findings across several scientific domains. We address this challenge by using a maximum variation sampling strategy (Suri, 2014).

To select the literature for inclusion in the literature review database, multiple searches were carried out on search terms such as "medical innovation," "medical and/or health-care innovation systems," and "innovation and hospitals/academic medical centers/university hospitals/research hospitals.” Identical searches were conducted in three databases with broad coverage: ISI Web of Science, Scopus, and PubMed. The first set of keyword searches was conducted in ISI Web of Science (WoS; on the title, keywords, and abstract) on the terms "innovation and hospitals," yielding 895 publications. Identical searches were conducted in Scopus and PubMed to verify that the searches generated the relevant research literature, thus validating our research strategy. Scopus and PubMed have broader coverage of publication types, including also books, book chapters, and practitioner-oriented publications. The procedure described in Table 1 was followed for each database. In Scopus and PubMed, the initial searches on innovation and hospitals yielded a larger number of hits $(15,072$ and 505$)$. In these databases, we set requirements that publications should include an abstract, and searches were conducted on title/abstract/keywords, to enable a replication of the search procedures.

As seen in Table 1, searching on the keywords "hospital" and "innovation" generates a large number of hits, which have to be reduced to meet review feasibility constraints. We therefore added a third term to narrow the scope of the search. After running the three queries, 307 abstracts from WoS, 638 abstracts from Scopus, and 203 abstracts from PubMed were downloaded and reviewed-a total of 1148 abstracts. All these abstracts were read, and a decision was made as to whether the text was relevant in accordance with the inclusion and exclusion criteria in Table 1 . The procedure was applied on abstracts and then on the full text of all documents that matched the criteria.

As an additional measure to ensure that we were not missing relevant publications, we also searched for publications that included the keywords "innovation" or "technology" in their title in selected journals that prior searches had identified as the four that published most frequently on this topic. This procedure provided information 


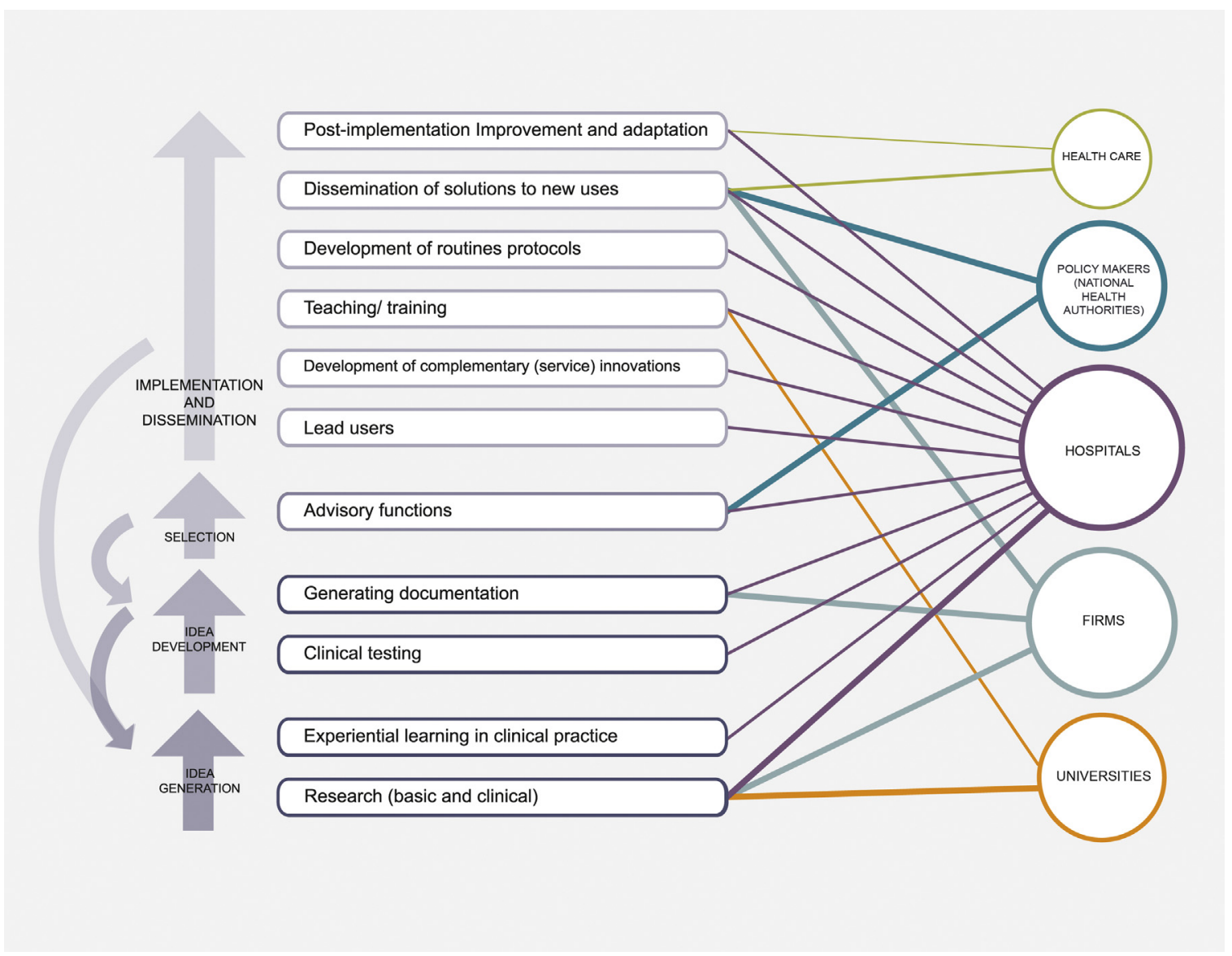

Fig. 1. The roles of hospitals in innovation.

Table 1

Search terms and literature database.

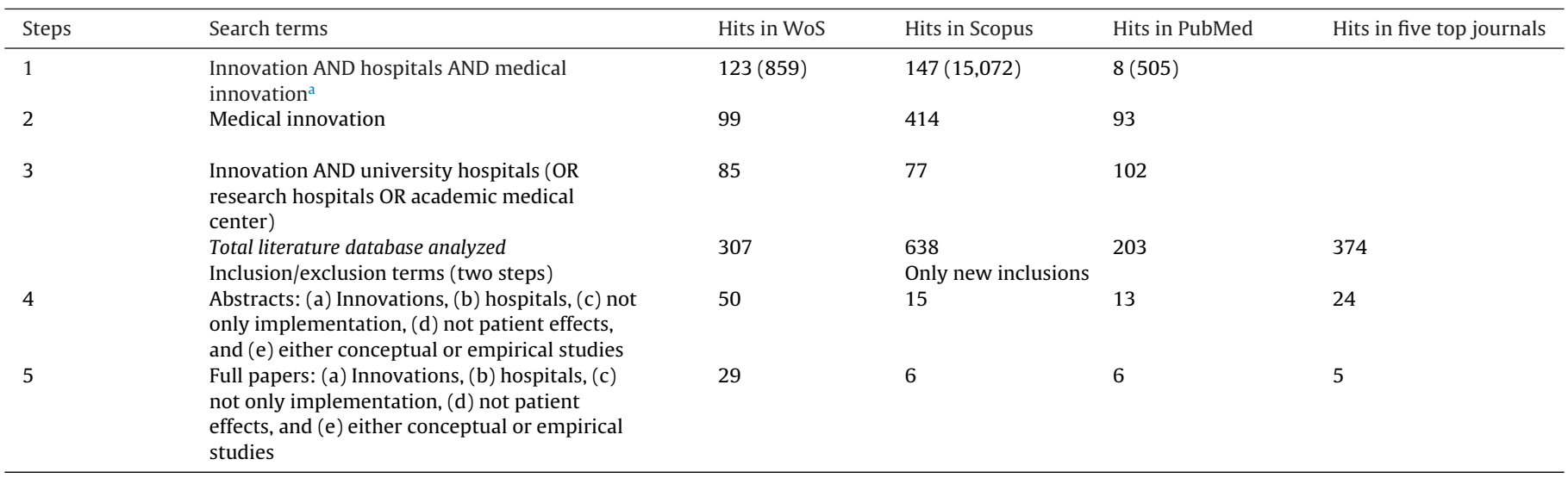

WoS $=$ Web of Science.

a Numbers in parentheses is the numbers of hits without adding the third search term "medical innovation" to the algorithm.

about 374 papers, of which 24 were added to the review database after the selection procedure was applied, and another six to the final set of papers.

To capture the literature that was relevant to our research interest, we defined two broad exclusion criteria, as described in Table 1. First, we excluded the extensive literature that addresses only the adoption and dissemination of innovations in the health-care context. Hospitals are large public organizations performing complex tasks through which they are simultaneously involved in a wide range of innovation processes. They involve adoption choices and adaptive behaviors connected to the implementation of new medical technologies and managerial practices, which tend to be treated in some detail in the health-care management and mainstream health economics literatures. These include the adoption of new information and communication technology (ICT) solutions as administrative tools (e.g., electronic medical records), also covered rather extensively in the information systems literature (for an overview of ICT-mediated service innovation, see Barrett et al., 2015). 


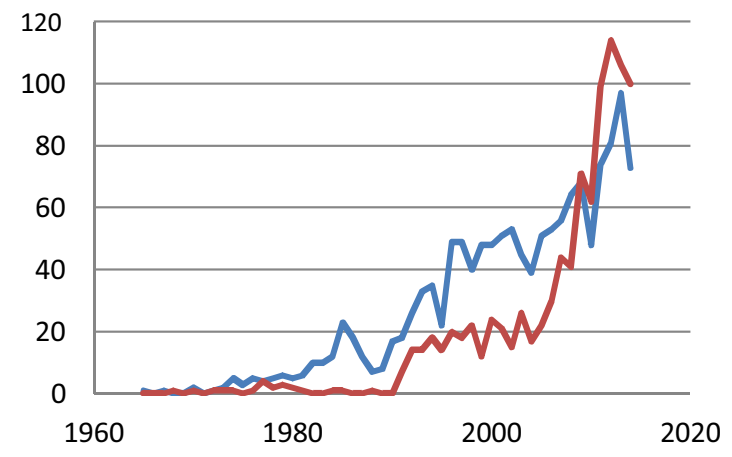

Publications in Scopus

Publications in ISI

Fig. 2. Publications on innovation AND hospitals in Scopus and WoS (1965-2014).

Table 2

Top publishing journals on innovation and hospitals in Scopus and WoS.

\begin{tabular}{|c|c|c|c|c|}
\hline & Top 10 journals Scopus & No. of publications & Top 10 journals WoS & No. of publications \\
\hline 1 & Hospitals Health Networks AHA & 110 & Health Affairs & 45 \\
\hline 2 & Health Care Management Review & 61 & Health Policy & 29 \\
\hline 3 & Social Science and Medicine & 57 & Implementation Science & 25 \\
\hline 4 & Academic Medicine & 54 & Social Science Medicine & 22 \\
\hline 5 & Harvard Business Review & 51 & BMC Health Services Research & 20 \\
\hline 5 & Healthcare Financial Management & 41 & Health Care Management Review & 20 \\
\hline 7 & Health Affairs & 34 & Journal of Nursing Administration & 20 \\
\hline 8 & Quality Management in Health Care & 29 & Journal of Advanced Nursing & 15 \\
\hline 9 & International Journal for Quality in Health Care & 28 & Journal of Clinical Nursing & 14 \\
\hline 10 & Medical Care & 27 & Journal of Healthcare Management & 13 \\
\hline
\end{tabular}

WoS $=$ Web of Science.

The vast literature on the implementation of medical or administrative innovation mainly describes how hospitals make technology adoption decisions or use innovations generated outside the hospital, which does not play a role in their generation. This is not to say that hospitals did not have a role in developing relevant new knowledge, but that this aspect of the innovation process is not the specific focus of the studies excluded from our database. They remain relevant for understanding implementation processes, but are less relevant if our objective is to understand how innovations are actively generated by or jointly with hospitals. Articles that link implementation to the generation of innovations have been included in the review. The same exclusion criterion was applied to literature that describes only the implementation of new treatment regimes, and to literature that addresses the efficiency and effectiveness of new innovations, without investigating how these innovations were developed or how hospitals or hospital staff contributed to the generation of these innovations.

The second exclusion criterion applied to the identification of relevant prior art concerned literature other than research papers, that is, papers that do not aim to increase scholarly knowledge about a particular question. This means that we included papers that present either new conceptual approaches or empirical studies of innovation in and by hospitals, and exclude opinion pieces, teaching cases, letters, and other kinds of published items that are not subject to peer review. The medical domain includes many such items: they have been read as part of the research context, but have not been included in the final review database.

The search processes exposed the importance of searching broadly for research literature that addresses the role of hospitals in innovation, because numerous approaches to the topic rooted in different disciplinary settings exist, and each has dedicated journals and specialist audiences. A wide variety of fields has published on this topic, with growing intensity over the past 15 years (Fig. 2).

Medical innovation and innovation in hospital/clinical settings have been addressed in economics and management, public health, health-care policy and management, innovation studies, sociol- ogy, science and technology studies, as well as in several medical and health care-related journals. The journals that have published most frequently on the topic, however, are in health-care policy and management, as well as in nursing-related journals. As Table 2 shows, there is not a great deal of overlap in top publishing journals in Scopus and ISI, except in the journals Health Affairs and Social Science and Medicine.

For the final set of 46 articles that matched all the inclusion criteria, further detailed analyses were conducted. Table 3 shows how the articles represent a variety of research questions, methodologies, and data. This makes it more difficult to generate a coherent picture of the relevant knowledge base. Most of the articles describe or analyze innovation processes or innovation systems in which hospitals of different kinds play vital roles. The units of analysis are the innovation process and the network of actors that over time have contributed to the development of innovations with specific resources. The role of hospitals is addressed in relation to other actors or complementary inputs that constitute the innovation system of reference. Studies addressing the role of hospitals or particular types of hospitals directly are rarer, and in this sample few articles deal with management of innovation in hospitals.

There are many data collection approaches, but only a few large quantitative studies. They are either based on surveys of a limited number of hospitals or use bibliometric or patent data. The articles are mostly case studies of particular diseases, medical technologies, or hospitals. Fourteen articles are cross-sectional studies comparing multiple units (mainly several hospitals).

In line with the review methodology that integrates both qualitative and quantitative studies (Suri, 2014), we coded the literature on key parameters, such as study topics, methods, and data sources (Table 3 ). We used mainly a study-oriented synthesis approach, in which we describe briefly the key findings of the target studies, rather than aggregate findings across the articles sampled. We interpret and discuss the literature, but refrain from conducting any quantitative meta-analysis of numerical results found in the empirical evidence: this would be neither possible nor advisable because 
Table 3

Research questions, data, and methodology in the final sample $(N=46)$.

\begin{tabular}{|c|c|}
\hline Key features of the articles & Number of articles \\
\hline \multicolumn{2}{|l|}{ Main research questions addressed } \\
\hline Characteristics of medical innovation processes & 15 \\
\hline Characteristics of medical innovation systems & 12 \\
\hline Role/s of particular participants in medical innovation (hospitals, clinical staff, medical doctors) & 10 \\
\hline Management and organization of medical innovation in hospitals & 7 \\
\hline Results/effects of medical innovation in hospitals & 2 \\
\hline \multicolumn{2}{|l|}{ Methods } \\
\hline Quantitative data & 17 \\
\hline Qualitative data & 13 \\
\hline Mixed methods & 8 \\
\hline Conceptual & 8 \\
\hline \multicolumn{2}{|l|}{ Empirical approach } \\
\hline Medical case study (targets particular areas of medical practice) & 9 \\
\hline Technological case study (targets particular medical technologies) & 9 \\
\hline Hospital case study (targets one or more particular hospitals) & 6 \\
\hline Cross-sectional (targets several units, multiple hospitals/technologies) & 14 \\
\hline Not an empirical study & 8 \\
\hline
\end{tabular}

of fundamental differences in the issues addressed, data sources used, and methodological approaches employed in the literature (Suri, 2014).

\section{Three strands of literature on hospitals and innovation}

We have divided the innovation literature that deals with hospitals and innovation into three strands based on the main analytical units they try to describe or explain. The first group of studies has a micro-level focus in that it addresses the contribution of particular types of hospital staff to the generation of innovations. The second group addresses, either conceptually or empirically, hospitals' innovation activities, based on case studies or small sample studies of particular institutions. It typically focuses on the role of hospitals in innovation by looking at innovation activities at specific hospitals or particular units at hospitals. The third group includes studies of technological and epistemological change in medicine, in which the units of analysis are networks or systems of innovation connected to particular problems, technologies, or areas of medical practice. On rare occasions, papers with a very broad scope appear in more than one group. The first group of papers tends to take a health-care or general management perspective. The second group is relatively more heterogeneous in approach and theoretical perspective, but papers share a strong focus on organizational features and on practices that promote innovation. The third group has a more coherent theoretical perspective and highlight the problem of long-term sociotechnical changes in medical innovation.

\subsection{Health-care practitioners and their contribution to innovation}

Many studies focus on particular groups of individuals active at hospitals and the health-care industry more generally (Table 4). These contributions dedicate special attention to medical doctors as generators of innovation in a line of research with strong links to von Hippel's (1988) foundational studies of user innovation. Medical doctors and clinical staff have played a prominent role in the development of new treatments and devices (Chatterji et al., 2008; Chatterji and Fabrizio, 2013; Kesselheim et al., 2014; Smith and Sfekas, 2013; Weigel, 2011). These studies range from quantitative analyses of patent statistics as indicators of invention by practitioners (Chatterji et al., 2008; Chatterji and Fabrizio, 2013; Smith and Sfekas, 2013) to case studies of particular medical devices (Kesselheim et al., 2014) or drugs (Xu and Kesselheim, 2014).

They generally point to two interrelated roles of medical doctors as far as innovation is concerned. First, the original ideas for new products emerge in clinical settings, when doctors find, for example, that existing devices do not solve problems or address needs satisfactorily in the clinical setting (Kesselheim et al., 2014). Several studies find that doctors are actively engaged in developing designs and early stage prototypes and experiment with different solutions. Utilizing information in US patent data on medical devices, Chatterji et al. (2008), Chatterji and Fabrizio (2013), and Smith and Sfekas (2013) demonstrate that a substantial proportion of the product ideas had indeed emerged from the activity of clinicians. These papers assess the relevance of ideas that originated with clinicians on medical device innovation and find that these ideas have a significant impact on subsequent innovation. Chatterji and Fabrizio (2013) also show that the input from patents held by medical doctors is greater in new technological areas and in the generation of radical innovations. These studies also link the role of doctors as inventors of medical devices to their role as lead users and key partners for medical device companies that further develop and commercialize medical devices (Smith and Sfekas, 2013), a pattern that is confirmed by the qualitative studies grouped in this research stream (Kesselheim et al., 2014; Weigel, 2011).

The paper by García-Goñi et al. (2007) relaxes the exclusive focus applied in this literature to the role of medical doctors. This insightful study looks at both managers in health-care organizations and frontline personnel. It considers their motivation for engaging in innovation processes connected to improved service provision and compares different degrees of participation and of motivation among different groups of staff. Overall, their comparative empirical analysis of different health-care professionals in six European countries finds that managers are significantly more motivated and more involved than frontline personnel (even though their preference may arguably be more sensitive to cost and efficiency concerns).

Finally, another contribution that widens the focus from medical doctors to other stakeholder groups-inside and outside healthcare organizations-is the study of open innovation platforms by Bullinger et al. (2012). The role of patients in medical innovation is often highlighted as important, but rarely explicitly investigated. Bullinger et al. (2012) look into the idea generation phase of new products and services in health care that entails open communication, particularly with patients and other interested stakeholders. They find that patients and interest groups are active and important members of innovation communities, particularly in cases of rare diseases, and are both sources of adequate problem definitions as well as innovative solutions to these problems. 
Table 4

Overview of papers on practitioners in health care and their role in innovation.

\begin{tabular}{|c|c|c|c|c|c|}
\hline Paper & Empirical object & Data & Key issues explored & $\begin{array}{l}\text { Kinds of } \\
\text { innovations }\end{array}$ & Role of hospital/s \\
\hline $\begin{array}{l}\text { Bullinger } \\
\text { et al. } \\
(2012)\end{array}$ & $\begin{array}{l}\text { User involvement in } \\
\text { innovation through } \\
\text { open innovation } \\
\text { platforms }\end{array}$ & $\begin{array}{l}\text { Quantitative; } \\
\text { communi- } \\
\text { cation } \\
\text { analysis }\end{array}$ & $\begin{array}{l}\text { Investigates the role of user oriented, } \\
\text { open innovation platforms in health } \\
\text { care }\end{array}$ & $\begin{array}{l}\text { Product and service } \\
\text { innovations (ideas) }\end{array}$ & $\begin{array}{l}\text { Participants in open } \\
\text { innovation (alongside } \\
\text { other users) }\end{array}$ \\
\hline $\begin{array}{l}\text { Chatterji } \\
\text { and } \\
\text { Fabrizio } \\
\text { (2013) }\end{array}$ & Medical doctors in US & Quantitative & $\begin{array}{l}\text { Investigates the contribution of } \\
\text { medical doctors to innovation in } \\
\text { medical devices }\end{array}$ & $\begin{array}{l}\text { Product innovation } \\
\text { (medical devices) }\end{array}$ & $\begin{array}{l}\text { Hospital-based physicians: } \\
\text { idea generation and } \\
\text { marketing }\end{array}$ \\
\hline $\begin{array}{l}\text { Chatterji } \\
\text { et al. } \\
(2008)\end{array}$ & Medical device firms & Quantitative & $\begin{array}{l}\text { Investigates the effect of prior } \\
\text { collaboration with medical doctors on } \\
\text { innovation performance (new } \\
\text { products) }\end{array}$ & $\begin{array}{l}\text { Product innovation } \\
\text { (medical devices) }\end{array}$ & $\begin{array}{l}\text { Hospital-based physicians } \\
\text { as lead users of medical } \\
\text { devices }\end{array}$ \\
\hline $\begin{array}{l}\text { García- } \\
\text { Goñi et al. } \\
(2007)\end{array}$ & $\begin{array}{l}\text { Hospital managers and } \\
\text { front line staff in six } \\
\text { European countries }\end{array}$ & Quantitative & $\begin{array}{l}\text { Investigates the perceptions and } \\
\text { motivations of different kinds of } \\
\text { hospital staff toward innovation in } \\
\text { health-care services provision }\end{array}$ & $\begin{array}{l}\text { Innovation in } \\
\text { service provision }\end{array}$ & $\begin{array}{l}\text { Hospital managers and } \\
\text { front line staff, attitudes, } \\
\text { motivation and degree of } \\
\text { involvement in generating } \\
\text { and implementing } \\
\text { innovations }\end{array}$ \\
\hline $\begin{array}{l}\text { Kesselheim } \\
\text { et al. } \\
\text { (2014) }\end{array}$ & $\begin{array}{l}\text { Clinical doctors as } \\
\text { "physician inventors" }\end{array}$ & Qualitative & $\begin{array}{l}\text { Investigates the processes and } \\
\text { individuals involved in coronary artery } \\
\text { stents }\end{array}$ & Product innovation & $\begin{array}{l}\text { Idea generation and early } \\
\text { experimentation in clinical } \\
\text { practice }\end{array}$ \\
\hline $\begin{array}{l}\text { Smith and } \\
\text { Sfekas } \\
(2013)\end{array}$ & Medical devices & Quantitative & $\begin{array}{l}\text { Investigates premarket approval } \\
\text { applications filed by medical device } \\
\text { firms and medical doctors contribution } \\
\text { to them }\end{array}$ & Product innovation & $\begin{array}{l}\text { Idea generation and early } \\
\text { experimentation in clinical } \\
\text { practice }\end{array}$ \\
\hline $\begin{array}{l}\text { Xu and } \\
\text { Kesselheim } \\
\text { (2014) }\end{array}$ & $\begin{array}{l}\text { Patents connected to } \\
\text { stent technologies }\end{array}$ & Quantitative & $\begin{array}{l}\text { Contribution to medical devices by } \\
\text { medical doctors }\end{array}$ & Product innovation & $\begin{array}{l}\text { Idea generation and early } \\
\text { experimentation in clinical } \\
\text { practice }\end{array}$ \\
\hline
\end{tabular}

\subsection{Hospitals as innovative organizations}

Approximately half the papers we analyzed address the role(s) of different kinds of hospitals in the generation of innovations (Table 5). A common theme across these contributions is the attempt to capture or conceptualize hospitals' innovativeness, on the grounds that this is undertheorized and underinvestigated (Djellal and Gallouj, 2007; Salge and Vera, 2009; Windrum and García-Goñi, 2008). This is a perspective shared with the research literature that treats hospitals as "hidden" research systems (Hicks and Katz, 1996; Lander, 2013; Lander and Atkinson-Grosjean, 2011). A common idea in this literature is that a considerable amount of R\&D and innovation is underestimated because they involve activities and participants that are not adequately captured by standard indicators, such as publications, patents, and new products. The development of new knowledge and ideas for new products and services emerges from a complex interplay among scientific units, clinical units, and commercial units and often involves incremental technology and process improvements through learning by doing, which are rather difficult to observe and measure systematically.

As can be seen in Table 5, this research stream is rather heterogeneous in terms of key questions, empirical objects, and methodology/data. These papers focus on hospitals in general (Djellal and Gallouj, 2005, 2007), hospitals in particular regions or countries (e.g., French and Miller, 2012; Salge, 2012; Salge and Vera, 2009; Schultz et al., 2012; Weigel, 2011; Wu and Hsieh, 2011) or particular kinds of hospitals, that is, academic medical centers (Anderson et al., 1994; Rosenberg, 2009). Within these diverse empirical contexts, a range of issues is explored. Several papers attempt to conceptualize hospital innovativeness (Anderson et al., 1994; Djellal and Gallouj, 2005, 2007; Rosenberg, 2009) or explore empirically hospitals' innovation projects (Salge, 2012; Salge and Vera, 2009). Other papers emphasize particular innovation activities or organizational practices to support innovation, including research and commercialization activities (French and Miller, 2012; Lander and Atkinson-Grosjean, 2011; Rosenberg, 2009). A final group of papers addresses organizational features and practices that are conducive to innovation, developing conceptualizations, such as hospitals as creative and learning organizations (Dias and Escoval, 2013, 2015; Hernandez et al., 2013; Lee and Hong, 2014; Ugurluoglu et al., 2013; Yang, 2014).

These papers also differ in the types of innovations they select and consider. Many focus on the role of hospitals in the generation of new or improved products (e.g., medical devices or new treatments/drugs) (Chatterji et al., 2008; Rosenberg, 2009; Weigel, 2011). However, the majority of studies in this group focus on the generation and implementation of novelty in medical services (treatment regimes, organizational practices, and patient care) (Schultz et al., 2012; Thakur et al., 2012) or a combination of product and process innovations (Anderson et al., 1994; Djellal and Gallouj, 2005, 2007).

Djellal and Gallouj (2005), for instance, conceptualize hospitals as service providers and focus on the multiple operations run by hospitals and on their outputs. Their claim is that innovation and improvement work can occur in all aspects of hospitals' operations. They therefore propose that hospital innovation is highly diverse, encompassing administrative, organizational, and medical practices that are bundled together in services.

Another example of an inclusive conceptualization of innovation is found in the work by Salge (2012) and Salge and Vera (2009), who draw upon the distinction between science, technology, innovation (STI) and doing, using, interacting (DUI) (Jensen et al., 2007) as modes of learning. Based on these notions, they identify two corresponding modes of hospital innovativeness: science-based and practice-based. They look at the relationship between investment in different kinds of innovation activities and performance and hypothesize that investments in both science-based and practicebased innovation are beneficial to hospital performance. More specifically, Salge (2012) investigates the organizational factors that influence sustained investment in these different kinds of innovation activities (science-based and practice-based). The results indicate temporal persistence in innovation activities, particularly in investments in science-based innovations, and that these are 
Table 5

Overview of literature on hospitals as innovative organizations.

\begin{tabular}{|c|c|c|c|c|c|}
\hline Paper & Empirical object & Data & Key issues explored & Kinds of innovations & Role of hospital/s \\
\hline $\begin{array}{l}\text { Anderson et al. } \\
\text { (1994) }\end{array}$ & $\begin{array}{l}\text { Academic medical } \\
\text { centers in US }\end{array}$ & $\begin{array}{l}\text { Conceptual/mixed } \\
\text { methods }\end{array}$ & $\begin{array}{l}\text { Roles of academic medical } \\
\text { centers in innovation }\end{array}$ & $\begin{array}{l}\text { Product and process } \\
\text { innovation within medicine }\end{array}$ & $\begin{array}{l}\text { Five roles for hospitals, generators of } \\
\text { innovation, adoption, evaluative, } \\
\text { advisory, training }\end{array}$ \\
\hline $\begin{array}{l}\text { Dias and Escoval } \\
\text { (2015) }\end{array}$ & $\begin{array}{l}\text { Portuguese } \\
\text { hospitals }\end{array}$ & Mixed methods & $\begin{array}{l}\text { The relationship between } \\
\text { hospitals as learning } \\
\text { organizations and innovation } \\
\text { performance }\end{array}$ & $\begin{array}{l}\text { Product, service and process } \\
\text { innovations }\end{array}$ & $\begin{array}{l}\text { Generation and adoption of new } \\
\text { medical practices }\end{array}$ \\
\hline $\begin{array}{l}\text { Dias and Escoval } \\
\text { (2015) }\end{array}$ & $\begin{array}{l}\text { Portuguese } \\
\text { hospitals }\end{array}$ & Mixed methods & $\begin{array}{l}\text { The relationship between } \\
\text { innovation and hospital } \\
\text { performance }\end{array}$ & $\begin{array}{l}\text { Product, service and process } \\
\text { innovations }\end{array}$ & $\begin{array}{l}\text { Generation and adoption of new } \\
\text { medical practices }\end{array}$ \\
\hline $\begin{array}{l}\text { Djellal and } \\
\text { Gallouj (2005) }\end{array}$ & Hospitals & Conceptual & $\begin{array}{l}\text { Hospitals as service providers } \\
\text { and their role in innovation }\end{array}$ & $\begin{array}{l}\text { Multiple forms of innovation in } \\
\text { hospitals, connected to } \\
\text { different outputs and services } \\
\text { performed }\end{array}$ & $\begin{array}{l}\text { Multiple, dependent on type of } \\
\text { innovation }\end{array}$ \\
\hline $\begin{array}{l}\text { Djellal and } \\
\text { Gallouj (2007) }\end{array}$ & Hospitals & Lit. Review & $\begin{array}{l}\text { Discuss different perspectives } \\
\text { on hospitals in innovation }\end{array}$ & $\begin{array}{l}\text { Hospital innovation as a broad } \\
\text { category, includes both } \\
\text { process, product and service } \\
\text { innovations }\end{array}$ & $\begin{array}{l}\text { Multiple, dependent on type of } \\
\text { innovation }\end{array}$ \\
\hline $\begin{array}{l}\text { French and Miller } \\
\text { (2012) }\end{array}$ & $\begin{array}{l}\text { Hospitals in a } \\
\text { Canadian region }\end{array}$ & Qualitative & $\begin{array}{l}\text { Introduces the concept of the } \\
\text { entrepreneurial hospital }\end{array}$ & $\begin{array}{l}\text { Biomedical research and } \\
\text { innovation }\end{array}$ & $\begin{array}{l}\text { Entrepreneurial, capitalizing on care } \\
\text { functions to perform in innovation }\end{array}$ \\
\hline $\begin{array}{l}\text { Hernandez et al. } \\
\text { (2013) }\end{array}$ & $\begin{array}{l}\text { Drivers of } \\
\text { patient-centered } \\
\text { innovations in } \\
\text { health-care } \\
\text { organizations }\end{array}$ & Qualitative & $\begin{array}{l}\text { The process of initiating } \\
\text { patient-centered innovations } \\
\text { in health care }\end{array}$ & $\begin{array}{l}\text { Organizational innovations } \\
\text { intended to make hospital } \\
\text { services more patient friendly }\end{array}$ & $\begin{array}{l}\text { Generating innovations in service } \\
\text { delivery, entails generating } \\
\text { organizational innovations within the } \\
\text { hospitals }\end{array}$ \\
\hline $\begin{array}{l}\text { Hicks and Katz } \\
\text { (1996) }\end{array}$ & $\begin{array}{l}\text { Collaboration } \\
\text { between R\&D } \\
\text { performing sectors }\end{array}$ & $\begin{array}{l}\text { Quantitative } \\
\text { bibliometric }\end{array}$ & $\begin{array}{l}\text { Hospitals as the hidden } \\
\text { research system }\end{array}$ & $\begin{array}{l}\text { Research in biomedicine and } \\
\text { health }\end{array}$ & Important as a venue for research \\
\hline Lander (2013) & $\begin{array}{l}\text { Translational } \\
\text { medicine } \\
\text { (immunology) }\end{array}$ & $\begin{array}{l}\text { Quantitative, } \\
\text { bibliometric }\end{array}$ & $\begin{array}{l}\text { University-hospital } \\
\text { collaboration }\end{array}$ & $\begin{array}{l}\text { Research in biomedicine and } \\
\text { health }\end{array}$ & Integration \\
\hline $\begin{array}{l}\text { Lander and } \\
\text { Atkinson- } \\
\text { Grosjean } \\
(2011)\end{array}$ & $\begin{array}{l}\text { Hospital-based } \\
\text { laboratories }\end{array}$ & $\begin{array}{l}\text { Conceptual and } \\
\text { qualitative }\end{array}$ & $\begin{array}{l}\text { Hidden role of hospitals in } \\
\text { innovation }\end{array}$ & $\begin{array}{l}\text { Biomedical innovation and } \\
\text { translational medicine }\end{array}$ & $\begin{array}{l}\text { Integration between clinical and } \\
\text { biomedical knowledge }\end{array}$ \\
\hline $\begin{array}{l}\text { Lee and Hong } \\
(2014)\end{array}$ & Hospitals in Korea & Quantitative & $\begin{array}{l}\text { Determinants of knowledge } \\
\text { sharing and innovation } \\
\text { behavior among hospital staff }\end{array}$ & $\begin{array}{l}\text { New ideas, technical tools, and } \\
\text { methods used within hospitals }\end{array}$ & Generation of new ideas \\
\hline $\begin{array}{l}\text { Raadabadi et al. } \\
\text { (2014) }\end{array}$ & Hospitals in Iran & Quantitative & $\begin{array}{l}\text { Cultures of entrepreneurship } \\
\text { in hospitals }\end{array}$ & Not specific & $\begin{array}{l}\text { Generation and experimentation with } \\
\text { new solutions }\end{array}$ \\
\hline Rosenberg (2009) & $\begin{array}{l}\text { Academic medical } \\
\text { centers }\end{array}$ & $\begin{array}{l}\text { Conceptual/ } \\
\text { qualitative }\end{array}$ & $\begin{array}{l}\text { Institutionalization to support } \\
\text { hybridization and linkages } \\
\text { between medicine and natural } \\
\text { sciences }\end{array}$ & Medical product innovations & $\begin{array}{l}\text { Collaboration between hospitals and } \\
\text { universities in biomedical and medical } \\
\text { device innovation }\end{array}$ \\
\hline Salge (2012) & $\begin{array}{l}\text { English hospitals } \\
\text { (NHS } \\
\text { organizations) }\end{array}$ & Quantitative & $\begin{array}{l}\text { Hospital investments in } \\
\text { innovation }\end{array}$ & $\begin{array}{l}\text { Science and practice-based } \\
\text { innovation }\end{array}$ & Generation of innovations \\
\hline $\begin{array}{l}\text { Salge and Vera } \\
\text { (2009) }\end{array}$ & $\begin{array}{l}\text { English hospitals } \\
\text { (National Health } \\
\text { Service [NHS] } \\
\text { organizations) }\end{array}$ & Quantitative & $\begin{array}{l}\text { Linkage between innovation } \\
\text { investment and clinical } \\
\text { performance }\end{array}$ & $\begin{array}{l}\text { Science-based and } \\
\text { practice-based innovation }\end{array}$ & Generation of innovations \\
\hline $\begin{array}{l}\text { Schultz et al. } \\
\text { (2012) }\end{array}$ & German hospitals & Quantitative & $\begin{array}{l}\text { Impact of innovation } \\
\text { management of hospitals } \\
\text { innovativeness }\end{array}$ & $\begin{array}{l}\text { Diffusion of different kinds of } \\
\text { innovations; focus on medical } \\
\text { process innovations/service } \\
\text { innovations }\end{array}$ & Really about diffusion? \\
\hline $\begin{array}{l}\text { Thakur et al. } \\
\text { (2012) }\end{array}$ & $\begin{array}{l}\text { Hospital executives } \\
\text { in the US }\end{array}$ & Qualitative & $\begin{array}{l}\text { Definitions of innovations } \\
\text { within health-care } \\
\text { organizations }\end{array}$ & Adoption of best practices & $\begin{array}{l}\text { Adopting and adapting new practices } \\
\text { to local contexts }\end{array}$ \\
\hline $\begin{array}{l}\text { Ugurluoglu et al. } \\
\text { (2013) }\end{array}$ & $\begin{array}{l}\text { Hospital managers } \\
\text { at } 250 \text { hospitals in } \\
\text { Turkey }\end{array}$ & Quantitative & $\begin{array}{l}\text { Characteristics of hospitals as } \\
\text { learning organizations and its } \\
\text { influence on innovation } \\
\text { performance }\end{array}$ & $\begin{array}{l}\text { Introduction of new medical } \\
\text { procedures }\end{array}$ & $\begin{array}{l}\text { Generation and adoption of new } \\
\text { medical practices }\end{array}$ \\
\hline Weigel (2011) & $\begin{array}{l}\text { Case study of one } \\
\text { hospital in } \\
\text { Germany }\end{array}$ & Qualitative & $\begin{array}{l}\text { The contribution of the hospital } \\
\text { to innovation in a regional } \\
\text { medical device industry }\end{array}$ & $\begin{array}{l}\text { Product innovation (medical } \\
\text { devices) }\end{array}$ & $\begin{array}{l}\text { Idea generation and leading partner in } \\
\text { all stages of development }\end{array}$ \\
\hline $\begin{array}{l}\text { Wu and Hsieh } \\
\text { (2011) }\end{array}$ & Hospitals in Taiwan & Quantitative & $\begin{array}{l}\text { Impact of innovations on } \\
\text { perceived quality of care }\end{array}$ & $\begin{array}{l}\text { Medical and administrative } \\
\text { innovations (products and } \\
\text { services) }\end{array}$ & $\begin{array}{l}\text { Adaption and development of } \\
\text { improved services toward patients }\end{array}$ \\
\hline Yang (2014) & Hospitals in Taiwan & Quantitative & $\begin{array}{l}\text { Determinants of innovation } \\
\text { capability and performance in } \\
\text { Taiwanese hospitals }\end{array}$ & $\begin{array}{l}\text { Innovative capability (ability to } \\
\text { generate novelty) }\end{array}$ & $\begin{array}{l}\text { Generation and adoption of new } \\
\text { medical practices }\end{array}$ \\
\hline
\end{tabular}

influenced by specialization levels, financial slack, and the strategic direction of hospitals over time. In addition, Schultz et al.
(2012) find that management approaches that encourage employee involvement have a positive effect on overall innovation portfo- 
lios (i.e., the number and range of innovation projects) in German hospitals.

In line with this perspective, several papers address the question of organizational characteristics and practices that may promote innovation at hospitals. These papers attempt to map whether hospital organizations foster learning, creativity, and entrepreneurial attitudes among employees (Dias and Escoval, 2015; García-Goñi et al., 2007; Hernandez et al., 2013; Lee and Hong, 2014; Raadabadi et al., 2014) and try to identify the influence such features have on hospitals' innovative capability (Ugurluoglu et al., 2013) and innovation performance (Dias and Escoval, 2013; Yang, 2014). The results are not conclusive but, overall, seem to indicate that hospitals with a strong focus on learning display higher innovation performance, in line with general innovation theory. Notably, however, these studies are not explicit about the types of innovations hospitals promote and whether these features are beneficial for the generation of novelty or implementation of and experimentation with innovative solutions.

A surprisingly small number of papers address the commercial aspects of hospital innovation activities. French and Miller (2012) focus on the increasing commercial ethos of Canadian hospitals and attempt to outline features of the "entrepreneurial hospital," which they define as "one that explicitly seeks to constitute patient populations and case infrastructures as distinctive assets (or resources) in pursuit of entrepreneurial aims" (p. 718). According to these authors, the data they collected through interviews indicate increasing awareness of the strategic value of clinical facilities and patients as assets for research and innovation, as well as for commercial exploitation of promising results. This is interpreted as an indication of changes in value regimes oriented not only toward the improvement of human health but also toward wealth creation, which constitutes a cultural shift, with pervasive but not well-known implications.

Despite their differences, the papers that belong to this first group of studies have the distinction of combining a relational view of hospitals as outward-looking organizations with an intraorganizational perspective with a focus on the heterogeneity of innovation activities and considerable differences that characterize different units involved in the generation of novelty at hospitals. These papers conceptualize the roles of hospitals in innovation in different ways. We can distinguish between papers that focus on hospitals as large and complex service organizations and those with a sharper focus on innovative products developed in a hospital context. Among the former, a key message is that hospitals perform multiple functions but that their role is that of system integrators across functions (Anderson et al., 1994; Djellal and Gallouj, 2005, 2007; French and Miller, 2012; Rosenberg, 2009; Salge, 2012; Salge and Vera, 2009). Among the latter papers, the focus on product innovation is associated with an emphasis on the role that hospitals and clinical sites play in idea generation and marketing, as well as implementation and post implementation improvements of new medical treatments and technologies (Schultz et al., 2012; Weigel, 2011; Wu and Hsieh, 2011).

\subsection{Hospitals' roles in innovation processes and systems}

The last group of studies identified in our database takes a systemic and longer-term view of medical innovation. They build, on the one hand, on the rich research tradition in the history of medicine and the history of technology and, on the other, on evolutionary approaches to innovation systems. They consider the characteristics and dynamic interplay of actors endowed with different (competing and complementary) bases of competence. Several papers focus on understanding innovation and technological developments in medicine from the viewpoint of a network of individuals and organizations that share the division of innova- tive labor. These networks, which often emerge to solve particular technical problems, co-evolve with changes in the knowledge base and underpin changes in the structure and composition of medical technology markets (Mina, 2009). Analyses of problem-driven innovation processes represent the empirical core of these studies.

The studies sampled for this review are only journal articles, as we used journal databases for literature searches. The sampled papers are closely related, however, and often based on historical and conceptual work in the 1990s on sociotechnical systems of medical technologies (Blume, 1992; Gelijns and Rosenberg, 1994; Rosenberg et al., 1995; Schlich, 2002), often published as books, book chapters, and reports. Detailed studies of the "careers" (Blume, 1992) of particular cases of medical technologies (e.g., medical imaging technologies, cochlear implants, artificial heart valves, endoscopes) led to a number of empirical observations about the generation and development of technologies in medicine, later summarized and used as the basis for renewed theoretical efforts in a series of publications included in Table 6.

As Table 6 shows, several papers emphasize particular medical objects (implants, heart valves, lenses, endoscopes, medical imaging technologies) or medical practices (telemedicine, ambulatory surgery, minimally invasive therapy, electronic patient records, patient registries) whereas others look at innovation from the vantage point of different medical problems (diseases or medical conditions, such as infection with HIV, heart disease, glaucoma, deafness). Although the empirical basis is different, what is common is nonetheless the ambition to track and explore the development of knowledge, technological and medical solutions, over time, within these defined contexts or cases. The papers emphasize innovations as the development of new products but also are embedded in service delivery. Thus, they look at innovations as both products (technical solutions or artefacts such as surgical tools, drugs, or particular procedures) and services (the use of tools in treatment/care situations). An important point is that products and process innovations are linked and that product innovations entail customization and adaptation, as well as the development of innovations in organizations and service delivery throughout customization and adoption processes (Petrakaki and Klecun, 2015). Compared to the first group of papers, these studies are less heterogeneous and focus on similar research questions, explanatory models, and research strategies. In terms of the latter, the studies are descriptive, often using a combination of data sources to generate a comprehensive image of epistemological, technological, and social developments in the case context.

These studies view innovation as long-term problem-solving processes, in which collaboration between different participants and competences is a key activity (Djellal and Gallouj, 2005, 2007; Galbrun and Kijima, 2009, 2010; Geljins and Fendrick, 1993; Geljins and Rosenberg, Rosenberg, 1994; Merito and Bonaccorsi, 2007; Metcalfe et al., 2005; Morlacchi and Nelson, 2011; Nelson et al., 2011; Rosenberg et al., 1995). A related focus is on how knowledge, technologies, markets, and institutions co-evolve over a considerable time seen ex post as particular trajectories of change. Human agency and creativity are drivers of innovation, because localized search and recombination of knowledge constitute key elements in problem-solving activities. However, technical changes in medicine do not involve only development and use of knowledge; the institutional framework, particularly regulation and demand formation, influence both creation and dissemination of new medical knowledge and medical practices (Metcalfe et al., 2005).

Furthermore, innovation processes in medicine are seen as recursive, with considerable interaction among invention, development, dissemination, and the use of new knowledge and technology. New medical innovations develop in an incremental manner and require substantial adaptation in many stages, consid- 
Table 6

Overview of papers on innovation processes and systems in health and medicine.

\begin{tabular}{|c|c|c|c|c|c|}
\hline Paper & $\begin{array}{l}\text { Empirical } \\
\text { object/case }\end{array}$ & Data & Key issues explored & Kinds of innovations & Role of hospitals \\
\hline $\begin{array}{l}\text { Barbera-Tomas and } \\
\text { Consoli (2012) }\end{array}$ & $\begin{array}{l}\text { Implantable } \\
\text { devices (artificial } \\
\text { discs) }\end{array}$ & Mixed methods & $\begin{array}{l}\text { Technological and scientific change } \\
\text { processes focusing on } \\
\text { developments of the knowledge } \\
\text { base and technological tools for } \\
\text { curing degenerative disk diseases }\end{array}$ & Product innovations & $\begin{array}{l}\text { Idea generation Clinical } \\
\text { experimentation and testing } \\
\text { Lead users } \\
\text { Procurement decisions and market }\end{array}$ \\
\hline $\begin{array}{l}\text { Consoli and Mina } \\
\text { (2009) }\end{array}$ & $\begin{array}{l}\text { Cardiology and } \\
\text { glaucoma }\end{array}$ & Mixed methods & $\begin{array}{l}\text { Evolutionary processes of medical } \\
\text { innovation, exemplified by } \\
\text { research on two areas of medical } \\
\text { practice }\end{array}$ & $\begin{array}{l}\text { Product and service innovations } \\
\text { connected to treatment of } \\
\text { particular medical conditions }\end{array}$ & $\begin{array}{l}\text { Basic and translational research, } \\
\text { problem formulation, idea } \\
\text { generation, experimentation and } \\
\text { testing, lead users and feedback }\end{array}$ \\
\hline $\begin{array}{l}\text { Consoli and } \\
\text { Ramlogan (2008, } \\
\text { 2011) }\end{array}$ & Glaucoma & $\begin{array}{l}\text { Conceptual } \\
\text { Mixed methods }\end{array}$ & $\begin{array}{l}\text { Process of knowledge growth in an } \\
\text { area of medicine }\end{array}$ & $\begin{array}{l}\text { Scientific development and } \\
\text { innovations in medical practices in } \\
\text { treating glaucoma }\end{array}$ & $\begin{array}{l}\text { Clinical research and collaborating } \\
\text { with academic research units }\end{array}$ \\
\hline $\begin{array}{l}\text { Essen and Lindblad } \\
\text { (2013) }\end{array}$ & Rheumatology & Qualitative & $\begin{array}{l}\text { Explores a practice-driven } \\
\text { innovation processes connected to } \\
\text { establishment and continuous } \\
\text { improvement of a national } \\
\text { rheumatology registry }\end{array}$ & $\begin{array}{l}\text { Product and service innovation (IT } \\
\text { based) }\end{array}$ & $\begin{array}{l}\text { Idea generation, continuous } \\
\text { improvement, users }\end{array}$ \\
\hline $\begin{array}{l}\text { Galbrun and Kijima } \\
(2009,2010)\end{array}$ & $\begin{array}{l}\text { Medical imaging } \\
\text { technology }\end{array}$ & Qualitative & $\begin{array}{l}\text { Dynamic relationships between } \\
\text { sets of actors that over time foster } \\
\text { innovation in medical technology }\end{array}$ & Product innovation & $\begin{array}{l}\text { Experiential learning leads to } \\
\text { innovation ideas and extends } \\
\text { usage of technology, } \\
\text { Lead users and testing functions, }\end{array}$ \\
\hline $\begin{array}{l}\text { Gelijns and } \\
\text { Fendrick (1993) }\end{array}$ & $\begin{array}{l}\text { Minimally invasive } \\
\text { therapy }\end{array}$ & Mixed methods & Dynamics of medical innovation & Products and procedures & $\begin{array}{l}\text { Idea generation, experimentation } \\
\text { and development of } \\
\text { supplementary service } \\
\text { innovations; complex interplay } \\
\text { with other agents }\end{array}$ \\
\hline $\begin{array}{l}\text { Gelijns and } \\
\text { Rosenberg (1994) }\end{array}$ & $\begin{array}{l}\text { Endoscopes, } \\
\text { medical imaging } \\
\text { technologies }\end{array}$ & $\begin{array}{l}\text { Conceptual, } \\
\text { qualitative }\end{array}$ & $\begin{array}{l}\text { Development of new medical } \\
\text { technologies, depends on close } \\
\text { interaction between producers and } \\
\text { users, and is influenced by changes } \\
\text { in regulation and financing of } \\
\text { health-care services, and patterns } \\
\text { of medical specialization. }\end{array}$ & $\begin{array}{l}\text { Product innovation (medical } \\
\text { devices) }\end{array}$ & $\begin{array}{l}\text { Adoption and adaption of } \\
\text { technologies developed elsewhere } \\
\text { for medical purposes } \\
\text { Clinical experimentation and } \\
\text { incremental improvements in } \\
\text { practice }\end{array}$ \\
\hline $\begin{array}{l}\text { Merito and } \\
\text { Bonaccorsi (2007) }\end{array}$ & HIV treatments & Mixed methods & $\begin{array}{l}\text { Co-evolution of clinical knowledge } \\
\text { and technology in development of } \\
\text { HIV treatments }\end{array}$ & $\begin{array}{l}\text { Product (drugs) and service } \\
\text { (treatment) }\end{array}$ & $\begin{array}{l}\text { Experiential knowledge, } \\
\text { experimentation and testing } \\
\text { Develops the complementary } \\
\text { social technologies needed for } \\
\text { widespread adoption }\end{array}$ \\
\hline $\begin{array}{l}\text { Metcalfe et al. } \\
(2005)\end{array}$ & Intra-ocular lenses & Mixed methods & $\begin{array}{l}\text { Dynamics of complex and } \\
\text { distributed innovation processes in } \\
\text { one area of medicine }\end{array}$ & $\begin{array}{l}\text { Service innovation (mode of } \\
\text { treatment/procedure) and product } \\
\text { innovations (implants) }\end{array}$ & $\begin{array}{l}\text { Idea generation, experimentation, } \\
\text { complementary innovations, lead } \\
\text { users, marketing }\end{array}$ \\
\hline Mina et al. (2007) & $\begin{array}{l}\text { Coronary artery } \\
\text { disease }\end{array}$ & Mixed methods & $\begin{array}{l}\text { Evolutionary trajectories of } \\
\text { change; complex, co-evolutionary } \\
\text { processes and path dependence }\end{array}$ & $\begin{array}{l}\text { Service innovation (mode of } \\
\text { treatment/procedure) and product } \\
\text { innovations (catheters and stents) }\end{array}$ & $\begin{array}{l}\text { Idea generation, research (clinical) } \\
\text { and experimentation }\end{array}$ \\
\hline $\begin{array}{l}\text { Morlacchi and } \\
\text { Nelson (2011) }\end{array}$ & $\begin{array}{l}\text { Left ventricular } \\
\text { assist device }\end{array}$ & Qualitative & $\begin{array}{l}\text { Evolutionary study of innovation } \\
\text { within one area of medical } \\
\text { practice, that involved interplay } \\
\text { between change in three related } \\
\text { areas: medical practice, science } \\
\text { and technology }\end{array}$ & $\begin{array}{l}\text { Product innovation (hart implant) } \\
\text { and service innovation (mode of } \\
\text { treatment) }\end{array}$ & $\begin{array}{l}\text { Problem formulation and idea } \\
\text { generation, experimentation and } \\
\text { testing, selection, develops } \\
\text { complementary innovations }\end{array}$ \\
\hline Nelson et al. (2011) & $\begin{array}{l}\text { Mainly conceptual, } \\
\text { some examples }\end{array}$ & Conceptual & $\begin{array}{l}\text { Innovation as an evolutionary } \\
\text { process involving learning in three } \\
\text { domains }\end{array}$ & $\begin{array}{l}\text { Service innovations (innovation in } \\
\text { treatment of diseases) }\end{array}$ & $\begin{array}{l}\text { Clinical practice, integration of } \\
\text { different sources of knowledge }\end{array}$ \\
\hline Nicolini (2010) & Tele-cardiology & Qualitative & $\begin{array}{l}\text { Development and dissemination } \\
\text { occur through network, and cannot } \\
\text { be meaningfully depicted in an } \\
\text { ordered stage-like form. Highlights } \\
\text { the political nature of health } \\
\text { innovations }\end{array}$ & $\begin{array}{l}\text { Product innovation } \\
\text { t(tele-monitoring) and service } \\
\text { innovation (mode of care) }\end{array}$ & \\
\hline $\begin{array}{l}\text { Petrakaki and } \\
\text { Klecun (2015) }\end{array}$ & $\begin{array}{l}\text { Electronic patient } \\
\text { records (EPR) }\end{array}$ & Qualitative & $\begin{array}{l}\text { Customization of EPR systems in } \\
\text { local settings; how } \\
\text { implementation often requires } \\
\text { local organizational and service } \\
\text { innovations }\end{array}$ & Product and service innovations & $\begin{array}{l}\text { Adopter, but creating local } \\
\text { customization and service } \\
\text { innovations }\end{array}$ \\
\hline $\begin{array}{l}\text { Ramlogan et al. } \\
\text { 2007) }\end{array}$ & $\begin{array}{l}\text { Coronary artery } \\
\text { glaucoma }\end{array}$ & Quantitative & $\begin{array}{l}\text { Evolutionary processes of medical } \\
\text { innovation, exemplified by } \\
\text { research on two areas of medical } \\
\text { practice }\end{array}$ & $\begin{array}{l}\text { Product and service innovations } \\
\text { connected to treatment of } \\
\text { particular medical conditions }\end{array}$ & $\begin{array}{l}\text { Basic and translational research, } \\
\text { problem formulation, idea } \\
\text { generation, experimentation and } \\
\text { testing, lead users and feedback }\end{array}$ \\
\hline $\begin{array}{l}\text { Windrum and } \\
\text { García-Goñi (2008) }\end{array}$ & $\begin{array}{l}\text { Ambulatory } \\
\text { surgery }\end{array}$ & $\begin{array}{l}\text { Conceptual and } \\
\text { qualitative }\end{array}$ & $\begin{array}{l}\text { Systems framework for exploring } \\
\text { health service innovation }\end{array}$ & $\begin{array}{l}\text { Service innovation (mode of } \\
\text { delivery of health services), } \\
\text { organizational innovation and } \\
\text { product innovation }\end{array}$ & $\begin{array}{l}\text { Developing and implementing a } \\
\text { new mode of service delivery }\end{array}$ \\
\hline
\end{tabular}


erable feedback from users, and considerable post-implementation development. It is hard to separate the creation of new knowledge and new technologies and the dissemination and use of these technologies in medical practices (Barbera-Tomas and Consoli, 2012; Consoli and Mina, 2009; Consoli and Ramlogan, 2008, 2011; Essen and Lindblad, 2013; Merito and Bonaccorsi, 2007; Mina et al., 2007; Petrakaki and Klecun, 2015). With this in mind, the point is made that the mainstream health-care management literature all too often separates implementation from innovation (Essen and Lindblad, 2013).

Morlacchi and Nelson (2011) claim that medical innovations or improved medical practices are the result of developments in three "co-evolving pathways": advances in biomedical scientific understanding, improvement of the ability to develop new medical technologies, and learning in (clinical) practice. These pathways correspond in part to organizations that "harbor" them (universities, firms, and hospitals), but since they are also interrelated and recursive, fluid networks and communities (of practices) that transgress each pathway are equally important. Because medical innovations draw on several sources of knowledge, "rich ecologies" of organizations-including universities, firms, hospitals, and research institutes-are involved in developing and dissemination of medical innovations (Nicolini, 2010; Ramlogan et al., 2007). At the same time, studies have also found that conflicts of interest between groups of professionals at hospitals and between hospitals and other organizations create barriers to innovation and that there is considerable resistance to developing and disseminating medical innovations (Blume, 1992; Nicolini, 2010). Increased specialization and potential intraprofessional competition, however, is also regarded as a driver for technological innovation in medicine (Gelijns and Rosenberg, 1994).

Hospitals and clinical sites are fundamental components of complex health innovation processes (Djellal and Gallouj, 2005, 2007; Geljins and Rosenberg, Rosenberg, 1994; Metcalfe et al., 2005; Morlacchi and Nelson, 2011; Nelson et al., 2011; Rosenberg, 2009; Rosenberg et al., 1995). This reflects again the importance of medical practice for identifying problems and solutions and points to the role of hospitals as "bridging organizations," where different pathways meet and are cross-fertilized. In other words, hospitals are one of many necessary actors in health innovation, but they have a key brokering role in bringing actors together in ways that should not be taken for granted (as if all network ties were persistent over time). In the distributed system of actors that are involved in the generation and development of innovations, hospitals are often the hubs in the broader network. As seen in Table 6, most papers describe multiple roles of hospitals or particular clinical sites at hospitals, ranging from initial idea generation to implementation and dissemination. However, in these papers, the hospital is not addressed as a unit. Rather, the focus is on clinical sites at hospitals, which have this key experimental learning and linking function intrinsically connected with innovation. Clearly, many of the innovations studied emerge out of medical practice, in which practitioners in health-care systems are involved in incremental and practice-driven improvement processes directed at improving conditions for patients (Essen and Lindblad, 2013).

As an extension of evolutionary studies of health innovation, with its focus on co-evolution across diverse sets of knowledge as a key to medical innovation, a system perspective of innovation in health and medicine is logically consistent. Among the papers included in the review are several attempts at conceptualizing health innovation systems in terms of participants and modes of interactions (Consoli and Mina, 2009; Djellal aand Gallouj, 2005, 2007; Galbrun and Kijima, 2010; Windrum and García-Goñi, 2008).

Consoli and Mina (2009) argue that health innovation systems consist of two broader domains: (1) the science and technology domain and (2) the practical domain or the health-care delivery system, with strong interactions within across domains. Hospitals are key actors in both domains, as well as brokers between them. Galbrun and Kijima (2010) use the concept "clinical innovation system" to describe the dual role of clinical sites in medical innovation. They also claim that the role of hospitals and clinical staff should not be understood merely in terms of their role in scientific investigations, testing new products, or implementing products or services. Clinical staff contribute to the generation of novelty by experimenting with technologies in treatment situations and by developing and implementing the social technologies or soft innovations (e.g., treatment protocols or advice for health-care policy on what solutions to procure/reimburse), which are necessary for wide-scale changes. This experimental function is carried out in clinical settings and makes hospitals the key arena for connections between science-based knowledge, technology and clinical practice, and between generation, selection, and dissemination of innovations.

Windrum and García-Goñi (2008) emphasize a third domain within the system: the policy domain, which to a great extent contributes to shaping how innovation processes occur and which innovations are selected. In traditional innovation models developed for understanding private sector innovation, the market is the important selection mechanism. For medical innovations, selection is much more complex and takes place in multi-agent environments with multiple selection criteria. Selection is strongly influenced by policy and policy makers, but policy also influences idea generation and regulates how new innovation develops. But the policy domain does not operate in isolation: feedback from medical and scientific communities also shapes policy-making, as do patients and patient groups.

The systems-oriented literature expands and supplements the micro-level investigations of particular cases of medical practice. The bridging role of hospitals looms even larger, not least because the system is large and complex with a multitude of actors that are highly different from one another in incentives and competence bases. In addition, these systems differ from related theoretical constructs that emphasize sectoral or geographic boundaries or that neglect the specific nature of public sector activities and the role of context-specific policy.

\section{Synthesis of findings}

The most obvious finding that emerges from our inspection of the literature is that the evidence base is highly heterogeneous. Relevant research has been published in several fields of science and various journals, and little consensus has been reached about key questions and overarching analytical frameworks. Most empirical studies published on hospitals and innovation are implementation studies, particularly implementation of new treatment regimes, ICT tools, or administrative routines in hospital settings, but investigations of the role of hospitals more broadly in the generation of novelty is a more recent area of interest (Salge and Vera, 2009). Multiple case studies have appeared on particular hospitals or specific innovations in medical technologies, treatment regimens, and drugs (see Table 6), but few attempts have been made to synthesize the evidence across this largely case-based repertoire of empirical evidence on how hospitals promote innovation.

Our literature review has identified three groups of studies, in which hospitals are seen as (1) the context of operation of innovative practitioners (a micro-level perspective),(2) the unit of analysis from an organizational viewpoint (a meso-level perspective), and (3) a central component and interface within a broader health innovation system (a more macro- or system-oriented perspective). The first two streams of papers encompass the activity of specific hospitals or groups of individuals at hospitals, whereas the third focuses 
on problems and the overall system through which innovations in medicine and health care emerge, develop, and spread. These approaches emphasize a multitude of roles for hospitals and hospital staff in innovation, but differ in their focus on different phases in innovation processes and also in whether they focus mainly on hospital internal roles versus roles carried out in collaboration with external actors in the wider health innovation system.

The different strands of literature largely emphasize different innovation activities and the hospitals' roles in them. Fig. 3 maps the different strands of literature onto the broad perspective of hospitals' roles in innovation, as described in Fig. 3.

Fig. 3 distinguishes four quadrants that represent the activities associated with different phases or dimensions of innovation: generation, development, verification/selection, and dissemination/use. The figure also distinguishes between an inner and an outer layer of activities, which represent, respectively, core hospital activities in innovation and innovation-related activities that hospitals perform in support of or in collaboration with external agents (including firms and regulators).

The first strand of contributions focuses on individuals or innovative practitioners and on their role in generating innovations in medicine and health care. As we have noted, this literature dedicates special attention to the role of medical doctors and looks in some detail at the role of clinicians as inventors, their role in developing new products, and the ways in which these activities are carried out in collaboration with industry.

The literature on hospitals as innovative organizations (strand 2 ) is, as expected, mainly hospital-internal oriented (it covers the four inner quadrants). Some of this literature also has a particular focus on use and dissemination, particularly on the question of complementary service innovations, customization, and post-implementation improvements. This literature has a learning/organizational perspective and tends to emphasize the organizational features and management practices that promote openness and participation in innovation activities among hospital employees.

The literature on technological trajectories (strand 3) takes into account a broader range of evolutionary patterns in medical innovation processes. It adopts a theoretical perspective that is less explicitly focused on the internal organization of hospitals but, like strand 2, connects new idea generation with the development and diffusion of innovation at the system level.

One fundamental problem that has received surprisingly little attention concerns the effects of technology selection and adoption on the current and future innovative capacity of hospitals. While technology assessment and technology adoption are well-researched themes in the field of health-care policy, the links between health-care policy and innovation policy are not a well-understood part of the health innovation system (Windrum and García-Goñi, 2008). In particular, the relationship between resourcing of hospital activities (in terms of equipment and skills), development of clinical practice and the growth of innovation capabilities within the organization are interesting and important avenue for further research. Overall, more research is needed on a micro-level analysis of practitioners' incentives for and engagement in innovation (including nurses and administrators) (Chatterji and Fabrizio, 2013; García-Goñi et al., 2007; Kesselheim et al., 2014), on the system-level implications of health-care technology funding and selection (Windrum and García-Goñi, 2008), and arguably on the connection between the micro and the macro levels of analysis.

Looking at the literature as a body of knowledge about hospitals and their role in medical innovation systems, the perspectives, empirical strategies, data, and methodologies used in current research have limitations. First, several studies have a relatively narrow scope and are often based on a limited set of empirical cases.
Very few studies are based on detailed information across multiple hospitals. Although some notable studies are exempt from this (e.g., García-Goñi et al., 2007; Salge, 2012; Salge and Vera, 2009), most published work does not utilize administrative data from hospitals to a large extent, although a large variety of data is available on investments in innovation, innovation processes, and outcomes in many countries and health systems.

Second, because empirical studies have targeted particular empirical objects, theoretical development has also tended to focus on relatively narrow perspectives. For instance, a systems perspective is evident in some of this literature (Consoli and Mina, 2009; Galbrun and Kijima, 2010; Windrum and García-Goñi, 2008), but delineation of the boundaries of the system differs across studies. Much work remains to be done in conceptualizing and describing different participants, activities, resources, relationships, and institutional frameworks in health innovation systems.

Third, the heterogeneous literature on hospitals and innovation has drawn upon conceptual frameworks and insights developed within the field of innovation studies to a limited extent. The literature on technological trajectories in health care and medicine draws on theoretical concepts from evolutionary studies of technology (e.g., Consoli and Mina, 2009; Metcalfe et al., 2005; Morlacchi and Nelson, 2011), but they have not always integrated the useful insights that can be derived from the application of organizational and managerial perspectives on innovation. The literature on hospitals as innovative organizations addresses hospital-internal matters and has focused on drivers of innovation, including organizational and management features that stimulate creativity and learning (Dias and Escoval, 2013, 2015; García-Goñi et al., 2007; Salge, 2012; Salge and Vera, 2009). But both the innovation systems literature on health care and organizational studies of hospitals as innovators often obscure the unit of analysis and neglect, respectively, the internal or external institutional complexity of hospitals.

\section{Concluding remarks and issues for further research}

Thematically, there is no shortage of issues for further research on the role of hospitals as innovators. First, as seen in Fig. 3, further research is needed on hospitals as selection environment for innovations and how this is related to hospitals' role in generation of innovations.

Second, the growing and pervasive emphasis on "open" innovation models calls for a careful assessment of the opportunities, and the costs, that increased engagement in innovation with external partners can bring. Interest in open innovation models in health care, particularly on patients and other stakeholders' involvement in innovation, is emerging (Bullinger et al., 2012). The governance of collaborative innovation requires experience as well as dedicated resources within the organization. It also requires a good understanding and appropriate design of incentives for researchers and clinical staff that are compatible with the delivery of health-care services (Salge et al., 2015).

Third, the capacity of hospitals to complement innovation activities carried out by external organizations (e.g., to collect evidence on experimentation with new drugs and devices), combined with the strong ties that research-intensive hospitals have with the university system, can dramatically increase incentives for companies to establish research facilities in the vicinity of hospitals in order to gain access to patients and to valuable knowledge. This may include the talent of graduates from research-intensive universities with strength in medicine and the life sciences or the intangible assets of smaller companies spun off from university departments and incubated in the local area (Mina and Probert, 2012). Therefore research hospitals can be significant factors in the location decisions of pharmaceutical and medical device companies. 


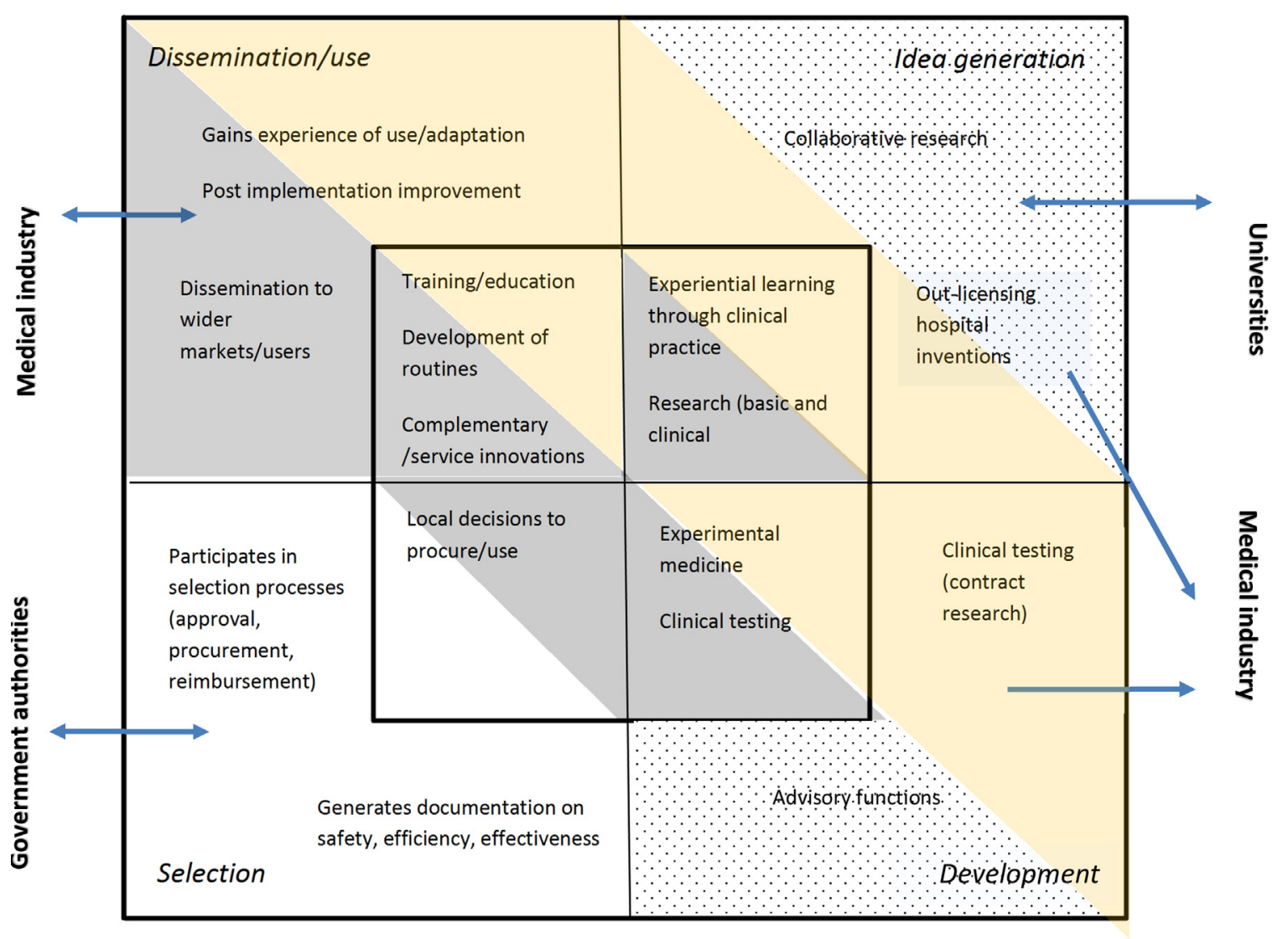

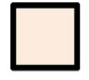

Literature on health innovation processes and systems processes and systems
Literature on hospitals as innovative organizations

Literature on innovative practitioners in health care

Fig. 3. The roles of hospitals in innovation and the main foci within different strands of literature.

Fourth, new ICT investments related to telemedicine and big data can provide new opportunities for learning if the information system of the health-care organization is designed to take full account of feedback mechanisms to guide further exploration in technology and practice.

To provide a more coherent evidence-based perspective on the role of hospitals in innovation, empirical studies with wider coverage are needed. Compared to universities and their role in innovation, which have been studied intensively over the past few years, the empirical basis on hospitals is much weaker and the conceptual and theoretical work more heterogeneous. In particular, studies are needed on innovation activities at the hospital level, which can be accomplished by collecting survey data at either the hospital or unit level and the individual level or by combining survey data with administrative data. Broader empirical studies and stronger theoretical models are also needed to underpin emerging innovation policy focusing on health and to inform stakeholders (owners, managers, practitioners, and patients) about the challenges of innovation-or lack thereof-especially in publicly funded health-care systems.

The literature review and analytical framework we present in this paper provide a starting point for further analysis of the roles of hospitals in the generation of innovation as guidelines that can be used to map actors, activities, relationships between actors and activities, their governance, and their outcomes. Because of the organizational and institutional complexity of hospitals, further empirical work should also look in some detail at departments, professional groups, and medical specialties within and across hospitals on a comparative and international basis.

\section{Acknowledgments}

Research for this article was funded by the Research Council of Norway under the project "Synergies and tensions in innovation in the life sciences," as well as by the South-Eastern Norway Regional Health Authority and the University of Oslo. The financial support received is gratefully acknowledged. The paper benefited greatly from insightful comments, criticism, and suggestions by the participants in medical innovation workshops held in Oslo (2013) and Gothenburg (2014), as well as by two anonymous reviewers and the editors of the special issue. The usual disclaimers apply.

\section{References}

Anderson, G., Steinberg, E., Heyssel, R., 1994. The pivotal role of the academic health center. Health Aff. 13 (3), 146-158.

Barbera-Tomas, D., Consoli, D., 2012. Whatever works: uncertainty and technological hybrids in medical innovation. Technol. Forecast. Social Change 79 (5), 932-948.

Barrett, M., Davidson, E., Prabhu, J., Vargo, S., 2015. Service innovation in the digital age: key contributions and future directions. MIS Quart. 39 (1), 135-154.

Blume, S., 1992. Insight and Industry: On the Dynamics of Technological Change in Medicine. MIT Press, Cambridge, Mass. 
Bullinger, A.C., Rass, M., Adamczyk, S., Moeslein, K.M., Sohn, S., 2012. Open innovation in health care: analysis of an open health platform. Health Policy 105 (2), 165-175.

Chatterji, A.K., Fabrizio, K.R., 2013. Using users: when does external knowledge enhance corporate product innovation? Strateg. Manage. J. 35 (10), 1427-1445

Chatterji, A.K., Fabrizio, K.R., Mitchell, W., Schulman, K.A., 2008. Physician-industry cooperation in the medical device industry. Health Aff. (Millwood) 27 (6), $1532-1543$.

Chesbrough, H., 2003. Open Innovation: The New Imperative for Creating and Profiting from Technology. Harvard Business School Press, Boston.

Chesbrough, H., 2006. Open Business Models: How to Thrive in the New Innovation Landscape. Harvard Business School Press, Boston.

Consoli, D., Mina, A., 2009. An evolutionary perspective on health innovation systems. J. Evol. Econ. 19 (2), 297-319.

Consoli, D., Ramlogan, R., 2008. Out of sight: problem sequences and epistemic boundaries of medical know-how on glaucoma. J. Evol. Econ. 18 (1), 31-56.

Consoli, D., Ramlogan, R., 2011. Patterns of organization in the development of medical know-how: the case of glaucoma research. Ind. Corp. Change 21 (2) 315-343.

Coombs, R., Harvey, M., Tether, B.S., 2003. Analysing distributed processes of provision and innovation. Ind Corp. Change 12 (6), 1125-1155.

Dahlander, L., Gann, D.M., 2010. How open is innovation? Res. Policy 39 (6), 699-709.

Dias, C., Escoval, A., 2013. Improvement of hospital performance through innovation: toward the value of hospital care. Health Care Manage. 32 (3) 268-279.

Dias, C., Escoval, A., 2015. Hospitals as learning organisations: fostering innovation through interactive learning. Oual. Manage. Health Care 24 (1), 52-59.

Djellal, F., Gallouj, F., 2005. Mapping innovation dynamics in hospitals. Res. Policy 34 (6), 817-835

Djellal, F., Gallouj, F., 2007. Innovation in hospitals: a survey of the literature. Eur. J. Health Econ. 8 (3), 181-193.

Essen, A., Lindblad, S., 2013. Innovation as emergence in healthcare: unpacking change from within. Soc. Sci. Med. 93, 203-211.

French, M., Miller, F.A., 2012. Leveraging the living laboratory: on the emergence of the entrepreneurial hospital. Soc. Sci. Med. 75 (4), 717-724.

Galbrun, J., Kijima, K.J., 2009. A Co-evolutionary perspective in medical technology: clinical innovation systems in Europe and in Japan. Asian J. Technol. Innov. 17 (2), 195-216.

Galbrun, J., Kijima, K.J., 2010. Fostering innovation in medical technology with hierarchy theory: narratives on emergent clinical solutions. Syst. Res. Behav. Sci. 27 (5), 523-536.

García-Goñi, M., Maroto, A., Rubalcaba, L., 2007. Innovation and motivation in public health professionals. Health Policy 84 (2), 344-358.

Gelijns, A.C., Fendrick, A.M., 1993. The dynamics of innovation in minimally invasive therapy. Health Policy 23 (1), 153-166.

Gelijns, A., Rosenberg, N., 1994. The dynamics of technological change in medicine. Health Aff. (Millwood) 13 (3), 28-46.

Hernandez, S.E., Conrad, D.A., Marcus-Smith, M.S., Reed, P., Watts, C., 2013. Patient-centered innovation in health care organizations: a conceptual framework and case study application. Health Care Manage. Rev. 38 (2), $166-175$.

Hicks, D., Katz, J.S., 1996. Hospitals: the hidden research system. Sci. Public Policy 23 (5), 297-304

Jensen, M.B., Johnson, B., Lorenz, E., Lundvall, B.Å., 2007. Forms of knowledge and modes of innovation. Res. Policy 36 (5), 680-693.

Kesselheim, A.S., Xu, S., Avorn, J., 2014. Clinicians contribution to the development of coronary artery stents: a qualitative study of transformative device innovation. PLoS One 9 (2), e88664.

Lander, B., Atkinson-Grosjean, J., 2011. Translational science and the hidden research system in universities and academic hospitals: a case study. Soc. Sci. Med. 72 (4), 537-544.

Lander, B., 2013. Sectoral collaboration in biomedical research and development. Scientometrics 94 (1), 343-357.

Lee, H.S., Hong, S.A., 2014. Factors affecting hospital employees knowledge sharing intention and behavior, and innovation behavior. Osong Public Health Res. Perspect. 5 (3), 148-155.

Littell, J.H., Corcoran, J., Pillai, V., 2008. Systematic Reviews and Meta-Analysis. University Press, Oxford, Oxford.

Merito, M., Bonaccorsi, A., 2007. Co-evolution of physical and social technologies in clinical practice: the case of HIV treatments. Res. Policy 36 (7), 1070-1087.
Metcalfe, J.S., James, A., Mina, A., 2005. Emergent innovation systems and the delivery of clinical services: the case of intra-ocular lenses. Res. Policy 34 (9), 1283-1304.

Mina, A., Probert, J., 2012. Enhancing Collaboration, Creating Value: Business Interaction with the UK Research Base in Four Sectors. Council for Industry and Higher Education (CIHE), London.

Mina, A., Ramlogan, R., Tampubolon, G., Metcalfe, J.S., 2007. Mapping evolutionary trajectories: applications to the growth and transformation of medical knowledge. Res. Policy 36 (5), 789-806.

Mina, A., 2009. The emergence of new knowledge, market evolution and the dynamics of micro-innovation systems. Econ. Innov. New Technol. 18 (5), 447-466.

Morlacchi, P., Nelson, R.R., 2011. How medical practice evolves: learning to treat failing hearts with an implantable device. Res. Policy 40 (4), 511-525.

Nelson, R.R., Buterbaugh, K., Perl, M., Gelijns, A., 2011. How medical know-how progresses. Res. Policy 40 (10), 1339-1344.

Nicolini, D., 2010. Medical innovation as a process of translation: a case from the field of telemedicine. Br. J. Manage. 21, 1011-1026.

Petrakaki, D., Klecun, E., 2015. Hybridity as a process of technology's translation: customizing a national Electronic Patient Record. Social Sci. Med. 124, 224-231.

Pickstone, J.V., 2011. Ways of knowing: a new history of science, technology, and medicine. University of Chicago Press, Chicago.

Raadabadi, M., Fayaz-Bakhsh, A., Nazari, A., Mousavi, S.M., Fayaz-Bakhsh, M., 2014. Organizational entrepreneurship and administrators of hospitals: case study of Iran. Global J. Health Sci. 6 (3), 249-255

Ramlogan, R., Mina, A., Tampubolon, G., Metcalfe, J.S., 2007. Networks of knowledge: the distributed nature of medical innovation. Scientometrics 70 (2), 459-489.

Rosenberg, N., Gelijns, A.C., Dawkins, H. (Eds.), 1995. Sources of Medical Technology: Universities and Industry. National Academy Press, Washington, $\mathrm{DC}$

Rosenberg, N., 2009. Some critical episodes in the progress of medical innovation: an Anglo-American perspective. Res. Policy 38 (2), 234-242.

Salge, T.O., Vera, A., 2009. Hospital innovativeness and organizational performance: evidence from English public acute care. Health Care Manage. Rev. 34 (1), 54-67.

Salge, T.O., Kohli, R., Barrett, M., 2015. Investing in information systems: on the behavioral and institutional search mechanisms underpinning hospitals' IS investment decisions. Manage. Inform. Syst. Quart. 39 (1), 61-89.

Salge, T.O., 2012. The temporal trajectories of innovative search: insights from public hospital services. Res. Policy 41 (4), 720-733.

Schlich, T., 2002. Surgery, Science and Industry: A Revolution in Fracture Care, 1950-1990s. Palgrave MacMillan Basingstoke, Hampshire, New York.

Schultz, C., Zippel-Schultz, B., Salomo, S., 2012. Hospital innovation portfolios: key determinants of size and innovativeness. Health Care Manage. Rev. 37 (2), $132-143$

Smith, S.W., Sfekas, A., 2013. How much do physician-entrepreneurs contribute to new medical devices? Med. Care 51 (5), 461-467.

Suri, H., 2014. Towards Methodologically Inclusive Research Syntheses: Expanding Possibilities. Routledge, London.

Thakur, R., Hsu, S.H.Y., Fontenot, G., 2012. Innovation in health care: issues and future trends. J. Business Res. 65, 562-569.

Ugurluoglu, O., Aldogan, E.U., Dilmac, E., 2013. The impact of managers perceptions of learning organisations on innovation in health care: sample of Turkey. Int. J. Health Plann. Manage. 28, 158-168.

Von Hippel, E., 1988. The Sources of Innovation. Oxford University Press, New York.

Weigel, S., 2011. Medical technology's source of innovation. Eur. Plann. Studies 19 (1), 43-61.

Windrum, P., García-Goñi, M., 2008. A neo-Schumpeterian model of health services innovation. Res. Policy 37 (4), 649-672.

Wu, I.L., Hsieh, P.J., 2011. Understanding hospital innovation enabled customer-perceived quality of structure, process, and outcome care. Total Qual. Manage. Business Excell. 22 (2), 227-241.

Xu, S., Kesselheim, A.S., 2014. Medical innovation then and now: perspectives of innovators responsible for transformative drugs. J. Law Med. Ethics 42 (4), $564-575$.

Yang, C.W., 2014. Implementing hospital innovation in Taiwan: the perspective of institutional theory and social capital. Int. J. Health Plann. Manage. 30, $403-425$. 